\title{
Cost Reduction Technique in Infrastructural Improvement Method for Slum Rehabilitation in Yenagoa, Bayelsa State, Nigeria
}

\author{
Andrew Feyaikebena Ebakpa, Akuro Ephraim Gobo, Sabastine Amauche Ngah* \\ Institute of Geo-Science and Space Technology, Rivers State University, Port Harcourt, Nigeria \\ Email: *ngahsab@yahoo.com
}

How to cite this paper: Ebakpa, A. F., Gobo, A. E., \& Ngah, S. A. (2017). Cost Reduction Technique in Infrastructural Improvement Method for Slum Rehabilitation in Yenagoa, Bayelsa State, Nigeria. Current Urban Studies, 5, 490-501. https://doi.org/10.4236/cus.2017.54028

Received: October 16, 2017

Accepted: December 25, 2017

Published: December 28, 2017

Copyright (c) 2017 by authors and Scientific Research Publishing Inc. This work is licensed under the Creative Commons Attribution International License (CC BY 4.0).

http://creativecommons.org/licenses/by/4.0/

\begin{abstract}
The poor state of sanitary services is a major environmental challenge in urban centres of Nigeria. The situation has reached a crisis proportion in the absence of basic sanitary services like modern toilet, good sewage management method, functional drainage system, good roads, environmentally-friendly solid waste disposal method, potable water, electricity and social amenities. The aim of the study is to show how infrastructural improvement method of slum rehabilitation can be applied to reduce costs for improving environmental quality of a major slum area in Yenagoa. Basic Research Methodology was applied using questionnaire, direct observation and personal interview techniques to collect data. Both qualitative and quantitative techniques were applied to analyse data through the use of tables and charts. The findings in the study showed that poor condition of sanitary services seriously degrades the environmental quality of the study area. The standard of living in the area is very poor as the people lack access to basic sanitation and social amenities. It showed that only $2 \%$ of the households exclusively use water closet (wc) toilet; $4 \%$ have well-maintained septic tanks; none of the houses are on road with functional drainage system; $10 \%$ of the houses are on tarred roads of 10 or more metres right-of-way and none of the households use environmentally-friendly solid waste management method.
\end{abstract}

\section{Keywords}

Cost Reduction Technique, Infrastructural Improvement Method, Slum Rehabilitation, Yenagoa, Bayelsa State, Nigeria

\section{Introduction}

The deplorable condition of sanitary services in the urban areas of Nigeria is a 
major source of concern due to the high prevalence of slums. This seriously degrades the environmental quality of the urban centres as they lack basic sanitary services. Lemma (2005) noted that "Slums are becoming inevitable phenomena of the urban fabric in the developing world". The UN-Habitat (2010) also defined slum as a contiguous settlement where the inhabitants are characterized as having inadequate housing and basic services. Igwilo (2004) and Vidal (2003) described slum as a group of buildings or an area in a state of deterioration and unsanitary conditions or absence of facilities amongst others where the health, safety or morals of its inhabitants are endangered. All over the globe, "over 880 million urban residents are estimated to live in slum conditions today, compared to 792 million reported in 2000 and 689 million in 1990" (United Nations, 2015, 2016). In Nigeria, the situation is not different (Ayotamuno \& Gobo, 2004; Owei \& Nwuzi, 2003).

Yenagoa, the capital of Bayelsa State of Nigeria, which was created on the 1st of October, 1996, is not an exception as the city lacks basic sanitary services (Ede et al., 2007; NBS, 2009). The population of the city increases on daily basis due to the uncontrollable influx of people into Yenagoa immediately the town was designated as the capital of Bayelsa State. Consequently, the environmental quality of the city is seriously degraded as the provision of sanitary services like good toilet, roads, sewage disposal method, drainage system as well as healthy solid waste management method/facilities among others cannot match the rapid population growth. The primary aim of the study is to show how cost reduction technique in infrastructural improvement method for slum rehabilitation can be applied for improvement of sanitary services in Yenagoa.

\section{Description of the Study Area}

The study was carried out within a major slum area in the central part of the city of Yenagoa in Bayelsa state. The area is bounded by Yenagoa-Mbiama road in the North, Harbour road in the west, Yenagoa-Oporoma road in the South, and Obele road in the East. It has a total land area of about 55.721 hectares $(0.55721$ sq. km) as also shown in Figure 1. The state capital territory lies between latitude $4^{\circ} 55^{\prime} \mathrm{N}$ and $4^{\circ} 57^{\prime} \mathrm{N}$; and longitude $6^{\circ} 16^{\prime} \mathrm{E}$ and $6^{\circ} 18^{\prime} \mathrm{E}$ as also shown in Figure 1. Yenagoa Local Government Area had a population of 151,298 persons in 1991, the total area is 706 square kilometre and the population density was 214 persons per square kilometre (Federal Republic of Nigeria, 1991). In 2006, the figure increased to about 266,008 persons and the population density was 376 persons per square kilometre (Federal Republic of Nigeria, 2009). Yenagoa had a linear pattern of settlement as at the time Bayelsa State was created. Presently, the original settlement pattern has changed with indiscriminate construction of houses without adequate basic sanitary services within and several kilometres beyond the native villages due to rapid population growth.

Yenagoa experiences heavy rainfall for eight to nine months (March to November) of the year with highest rainfall values obtained in the months of June 


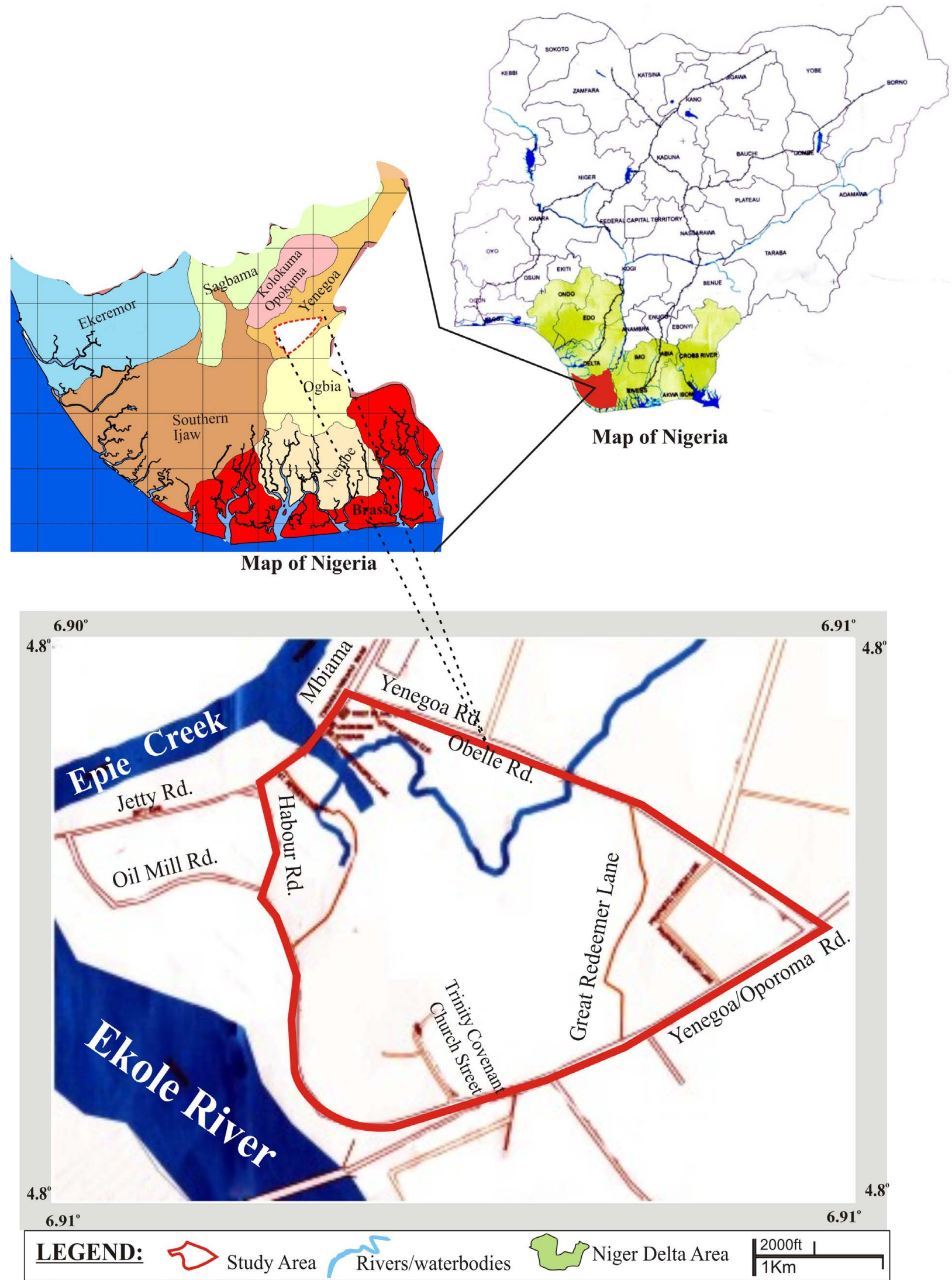

Figure 1. Map of the study area. 
(322.92 $\mathrm{mm})$, July $(413.59 \mathrm{~mm})$, August $(438.34 \mathrm{~mm})$ and September (439.84 $\mathrm{mm}$ ) while the mean annual rainfall is $3191 \mathrm{~mm}$ (Harcourt Adukeh Associates, 2004; Adejuwon, 2012). Even the dry season months of December, January and February are not free from occasional rainfall. Due to the low terrain, swamps, high rainfall and other unfavourable climatic factors, most parts of Yenagoa are flooded for about 8 or 9 months of the year especially during the flood season from the months of May to October. It is very expensive to provide sanitary services like good toilet, septic tank, drainage system, access road and solid waste management facilities among others in Yenagoa as it requires land reclamation and sand-filling due to the low terrain and unfavourable climatic factors.

\section{Methodology}

The research design for the study is Basic Research methodology using questionnaire for data collection. The data collection techniques include questionnaire and administration, observation of physical environmental condition and personal interviews. The respondents in the study are household heads in the area. Personal interviews were also conducted to gather data from government officials and community leaders. All houses in the area are considered as the population for the study. Sample frame was prepared comprising all roads and houses in the area. There are 62 roads in the area and the total number of houses is 1752 . On each of the roads, $25 \%$ of the houses were selected for assessment giving a sample size of 438 from which one household head was picked as a respondent for the study. Simple random sampling technique was applied to pick one out of the first two houses on each road in the sampling frame as starting point. Subsequently, systematic sampling method was used to pick houses for the study with a fixed periodic interval of 4 on each of the 62 roads. Both qualitative and quantitative data analysis techniques were used to interpret and explain the personal characteristics of household heads, condition of housing and sanitary services in the study area. These are analysed (described) through the use of statistical tools such as tables and charts.

\section{Results and Discussion}

\subsection{Type and Use of Toilet}

Table 1 shows the type of toilet in the three communities of the study area. From the table here provided, it shows that $73 \%$ of the houses use environmentally-unfriendly types of toilet as $40 \%$ use pit latrine while $33 \%$ are without toilet. This shows that most of the houses in Yenagoa were built without provision of toilet. The households without toilet defecate at any nearby unauthorized places thereby polluting the soil as well as water resources in the area. The study discovered that the area lacks adequate basic sanitation facilities as also identified in the informal settlements of Kisumu in Kenya by Simiyu (2015). The results on Figure 2 also show that only $8 \%$ of the 118 households that have water closet 
Table 1. Distribution of toilet by community.

\begin{tabular}{ccccccccccccc}
\hline \multirow{2}{*}{ Settlement } & \multicolumn{2}{c}{01} & \multicolumn{2}{c}{02} & \multicolumn{2}{c}{03} & \multicolumn{2}{c}{04} & \multicolumn{2}{c}{05} & \multirow{2}{*}{ Total } & $\%$ \\
\cline { 2 - 9 } & No. & $\%$ & No. & $\%$ & No. & $\%$ & No. & $\%$ & No. & $\%$ & & \\
\hline Obele & 53 & 12 & - & - & 71 & 16 & - & - & 47 & 11 & 171 & 39 \\
Ololo & 8 & 2 & - & - & 55 & 13 & - & - & 63 & 14 & 126 & 29 \\
Igugu & 57 & 13 & - & - & 48 & 11 & - & - & 36 & 8 & 141 & 32 \\
Total & 118 & 27 & - & - & 174 & 40 & - & - & 146 & 33 & 438 & 100 \\
\hline
\end{tabular}

Source: Authors' Fieldwork. Rating: (01-Water closet); (02-Pail system); (03-Pit latrine); (04-Bucket system); (05-No toilet).

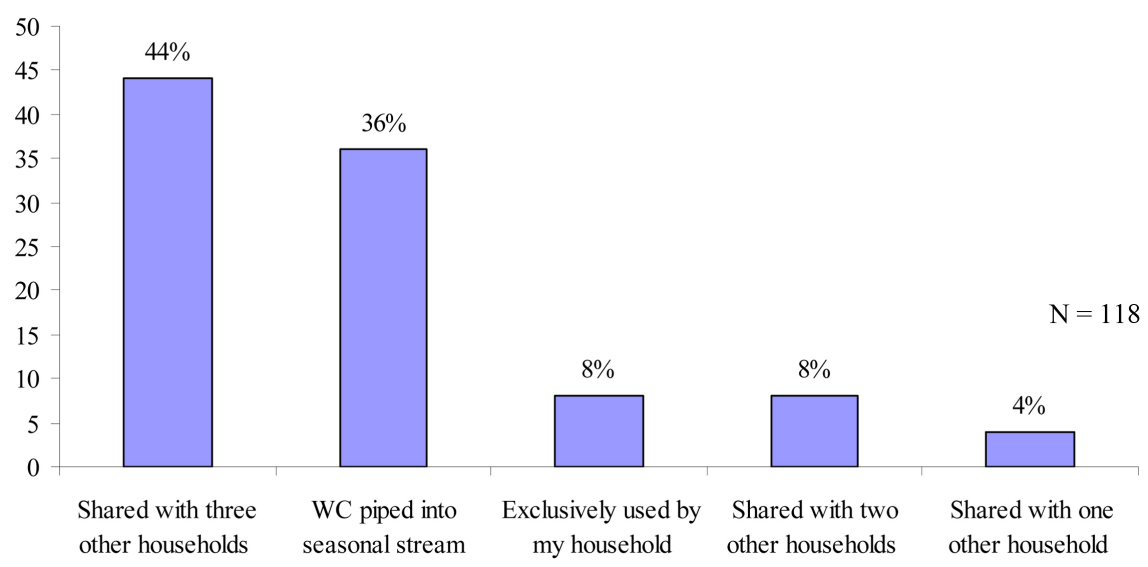

Figure 2. Use of water closet (wc) toilet. Source: Authors' fieldwork.

toilet exclusively use them. It conform to the findings by Ezenagu (2000) that the use of toilet facilities by too many persons create maintenance problems and frequent damages on the facilities. The above findings are collectively responsible for the incessant exposure of human feaces in the area that degrade the environmental quality of Yenagoa. The findings of the study show that the residents of the area would suffer health challenges if they live in this unhealthy condition for so long. They are exposed

\subsection{Sewage Disposal Method}

Table 2 shows the condition of septic tank (sewage disposal method) within the premises of the 76 houses that were built with provision of septic tank. From the table, only $22 \%$ of the 76 houses are provided with well-maintained septic tanks, $54 \%$ are with septic tanks that require minor repairs, $8 \%$ are with septic tanks that require major repairs while $16 \%$ of the septic tanks are either due for evacuation or dilapidated. This shows that the environmental quality of Yenagoa is very poor in terms of provision and maintenance of sewage disposal system (septic tank) in the area. The results in Figure 3 show that $64 \%$ of the 118 houses that use water closet toilet piped them to septic tank while the rest $36 \%$ of the water closet (WC) toilets are piped into seasonal streams. The above findings show that the area is exposed to serious unsanitary conditions that create 
Table 2. Condition of sewage disposal system (septic tank).

\begin{tabular}{ccc}
\hline Condition & No. & $\%$ \\
\hline Well-maintained & 17 & 22 \\
Required minor repairs & 41 & 54 \\
Requires major repairs & 6 & 8 \\
Due for evacuation or dilapidated & 12 & 16 \\
Total & 76 & 100 \\
\hline
\end{tabular}

Source. Authors' fieldwork.

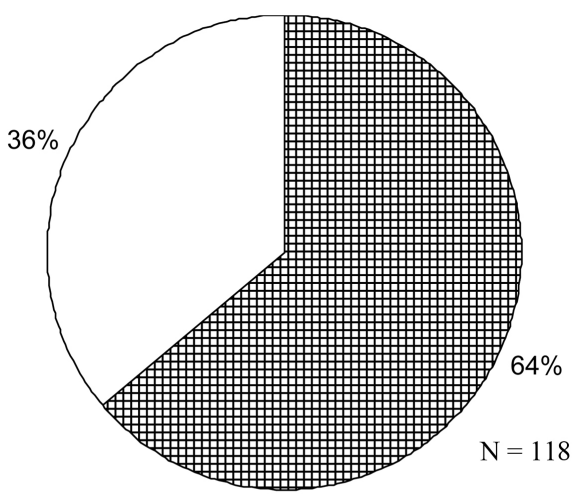

田 Water Closet Toilet piped into septic tank

$\square$ Water Closet Toilet piped into Seasonal Stream

Figure 3. Use of Sewage disposal method (septic tank). Source. Authors' fieldwork.

environmental pollution and degradation in the city. The implication is that this can cause health challenges to the residents which were also identified by Srinivas (2009). It was observed that human faeces are exposed from some of the septic tanks that are in a state of disrepair. This would cause several environmental hazards and diseases like cholera, dysentery and skin infection as also identified by Olokesusi and Ogu (1998). The sewage effluent discharged into the streams pollutes water resources and destroys aquatic lives due to eutrophication. It was observed that the discharge of too much nutrients in the form of nitrogen and phosphorous compounds amongst other pollutants into the streams through the sewage effluent accelerate the growth of algae and other aquatic plants as also identified by Enger and Smith (2004).

\subsection{Drainage System}

Table 3 shows distribution of drainage system by community as regards the present state of drainage system. The present condition of drainage system in the study area is deplorable as it creates adverse effects on the environmental quality of Yenagoa. This is evidenced in Table 3 where the present situation in terms of provision of drainage system is analysed within the premises of the houses in the study area. The results show that the condition of drainage system in the study area is not healthy as none of the houses is along a road with covered and flowing 
drainage system, $16 \%$ of the houses are along roads with either covered or open blocked drainage system, while the rest $84 \%$ are on roads without drainage system. This is a threat to the health of residents. The study identified that stagnant waste water pools are created in the area which are breading grounds for mosquitoes, offensive odour and unsightliness among others which also caused a bubonic plague in Lagos as identified by Duruzoechi (1999). The results in Figure 4 also show that none of the houses have an allowance (setback) of up to five metres from the utility line, $9 \%$ of the houses are less than five metres from the utility line while the rest $91 \%$ of the houses are built on the utility line. The above findings show that only $9 \%$ of the owners of the houses in the area gave an allowance (front setback) of less than five metres which is not adequate for provision of drainage system and other utilities. The rest $91 \%$ did not give any space (setback) for this important sanitary service and other public utilities. This shows that none of the property owners met the government approved standard of a minimum of five metres away from the utility line. The study identified inadequate space (setback) between houses and utility line as the cause of flooding

Table 3. Distribution of drainage system by community.

\begin{tabular}{ccccccccccccc}
\hline \multirow{2}{*}{ Settlement } & \multicolumn{2}{c}{01} & \multicolumn{2}{c}{02} & \multicolumn{2}{c}{03} & \multicolumn{2}{c}{04} & \multicolumn{2}{c}{05} & \multirow{2}{*}{ Total } & $\%$ \\
\cline { 2 - 10 } & No. & $\%$ & No. & $\%$ & No. & $\%$ & No. & $\%$ & No. & $\%$ & & \\
\hline Obele & - & - & - & - & 2 & 1 & 32 & 7 & 137 & 31 & 171 & 39 \\
Ololo & - & - & - & - & 8 & 2 & - & - & 118 & 27 & 126 & 29 \\
Igugu & - & - & - & - & 30 & 6 & - & - & 111 & 26 & 141 & 32 \\
Total & - & - & - & - & 40 & 9 & 32 & 7 & 366 & 84 & 438 & 100 \\
\hline
\end{tabular}

Source: Authors' fieldwork. Rating: 01-Covered drainage system and flowing. 02—Open drainage system but flowing. 03-Covered drainage system but not flowing (blocked with solid wastes). 04-Open drainage system and not flowing (blocked with solid wastes). 05-No drainage system.

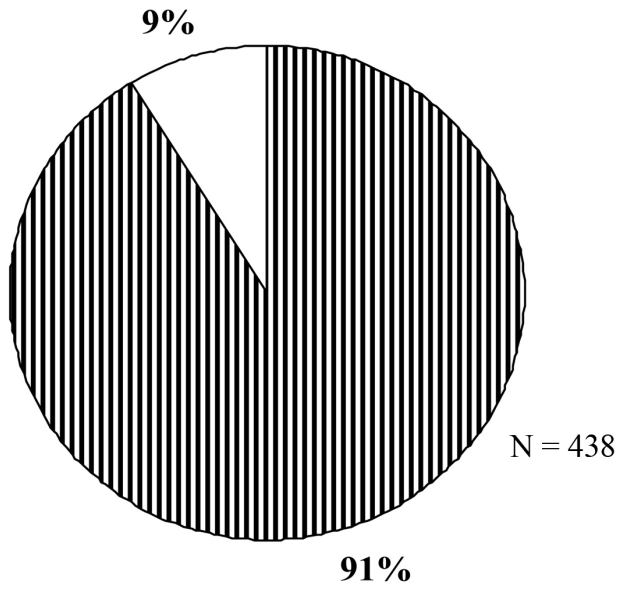

Ш House built within utility line

$\square$ House built less than five meters from utility line

Figure 4. Setback between houses and utility line. Source. Authors' fieldwork. 
in Yenagoa throughout the year as also identified in Abuja by Jinadu (2004). The study also observed that houses are even built on natural drainage paths which worsen the flooding problem in the state capital as the free flow of storm water is obstructed.

\subsection{Roads}

Table 4 shows condition of roads in front of houses in the area. The findings show that the area lacks functional access roads as only $10 \%$ of the houses are along tarred roads of 11 or more metres right-of-way without pothole, 3\% are along tarred roads of $10-10.9$ right-of-way with potholes, while the rest $87 \%$ of the houses are either along tarred narrow roads of less than 10 metres right-of-way, un-tarred roads or not on any access road. This indicates that the people lack good road network due to lack of land-use planning as identified by Obateru (2003). The findings in Figure 5 further show that the total number of roads in the area is 62 , only $6 \%$ out of the roads are tarred and without pothole, $2 \%$ is partly tarred while the rest $92 \%$ are un-tarred or less than 10 metres right-of-way. This shows that residents of the area find it difficult to drive to

Table 4. Condition of roads by community.

\begin{tabular}{|c|c|c|c|c|c|c|c|c|c|c|c|c|}
\hline \multirow{2}{*}{ Settlement } & \multicolumn{2}{|c|}{01} & \multicolumn{2}{|c|}{02} & \multicolumn{2}{|c|}{03} & \multicolumn{2}{|c|}{04} & \multicolumn{2}{|c|}{05} & \multirow{2}{*}{ Total } & \multirow{2}{*}{$\%$} \\
\hline & No. & $\%$ & No. & $\%$ & No. & $\%$ & No. & $\%$ & No. & $\%$ & & \\
\hline Obele & 2 & 1 & - & - & - & - & 14 & 3 & 155 & 35 & 171 & 39 \\
\hline Ololo & 8 & 2 & - & - & - & - & - & - & 118 & 27 & 126 & 29 \\
\hline Igugu & 32 & 7 & - & - & - & - & - & - & 109 & 25 & 141 & 32 \\
\hline Total & 42 & 10 & - & - & - & - & 14 & 3 & 382 & 87 & 438 & 100 \\
\hline
\end{tabular}

Source: Authors' fieldwork. Rating: 01-Tarred road of 11 or more metres right-of-way and without pothole. 02-Tarred road of 10-10.9 metres right-of-way but without pothole. $03-$ Tarred road of 11 or more metres right-of-way but with potholes. 04-Tarred road of 10-10.9 metres right-of-way and with potholes. 05-Tarred road of less than 10 metres right-of-way/un-tarred/no access road.

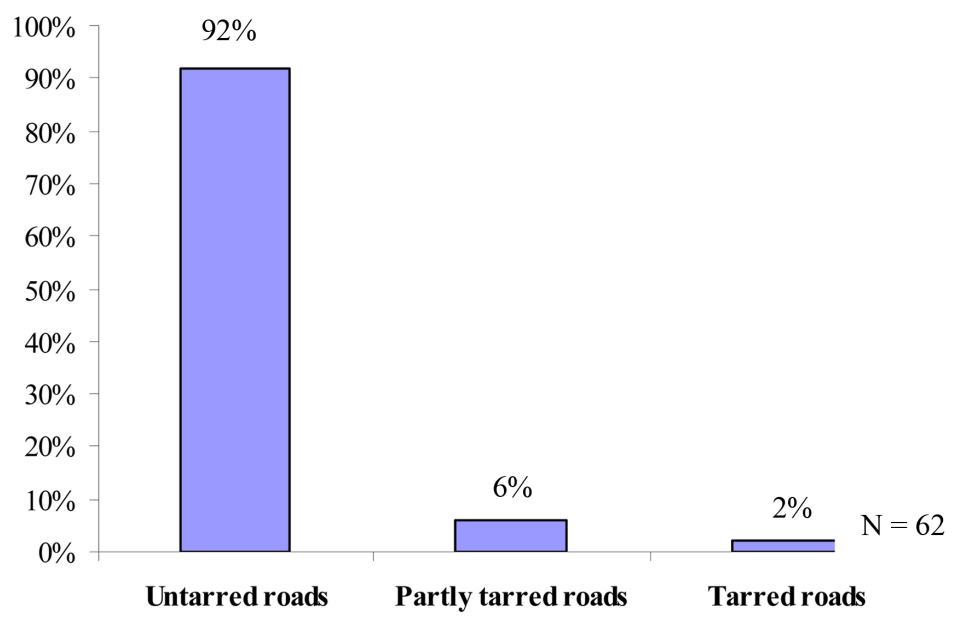

Figure 5. Condition of 62 roads in the study area. Source: Authors' fieldwork. 
their houses. This is also responsible for the high cost of building construction in the area it is difficult to transport building materials to project sites. The study identified lack of functional access roads in the area as a major factor responsible for traffic congestion in the city where residents who cannot access their houses pack vehicles on the few available roads as also identified in Abuja by Jiriko (2012). The study also identified lack of functional access roads in the area as the factor responsible for irregular evacuation of septic tanks in the area. It is even more expensive to evacuate septic tanks in the area as evacuation trucks cannot directly gain access to houses that are not along access road. The problem of insecurity in the area is also attributable to lack of access roads. The deplorable state of roads in the area is a major factor responsible for the inability of security agents to effectively fight crime in the area where patrol van cannot access houses. The lack of access roads in the area is a product of negligence on the part of government in terms of land-use planning and implementation as also identified by Olurin (2016).

\subsection{Solid Waste Management Method}

Table 5 shows the solid waste management methods by residents of the area. The findings show that none of the households in the study area sorted and pack solid wastes into special sanitation bags as requested by the Sanitation Authority of the state, $73 \%$ pack solid wastes either into special sanitation bags without sorting or open containers without cover, while the rest $27 \%$ of the households dump solid wastes either behind buildings, by road-sides or into seasonal streams. The findings on solid waste management in the area attest to the fact that the environmental quality of the area is very poor. The solid waste management methods commonly practiced by residents of the area are environmentally-unfriendly. The findings in Figure 6 further show that solid wastes are not frequently evacuated from central waste collection centres in the area. The study shows that there are 9 central solid waste collection centres in the area, 7 are evacuated once a week while the rest 2 are evacuated twice a week. This shows that solid wastes in the central waste collection centres in the area are not evacuated on daily basis. The implication is that residents of the area are exposed to

Table 5. Solid waste management method.

\begin{tabular}{cccccccccccccc}
\hline \multirow{2}{*}{ Settlement } & \multicolumn{2}{c}{$\mathbf{0 1}$} & \multicolumn{2}{c}{$\mathbf{0 2}$} & \multicolumn{2}{c}{$\mathbf{0 3}$} & \multicolumn{2}{c}{$\mathbf{0 4}$} & \multicolumn{2}{c}{05} & \multirow{2}{*}{ Total } & $\%$ \\
\cline { 2 - 10 } & No. & $\%$ & No. & $\%$ & No. & $\%$ & No. & $\%$ & No. & $\%$ & & \\
\hline Obele & - & - & - & - & 11 & 2 & 104 & 25 & 51 & 12 & 171 & 39 \\
Ololo & - & - & - & - & 6 & 1 & 90 & 21 & 30 & 7 & 126 & 29 \\
Igugu & - & - & - & - & 17 & 4 & 87 & 20 & 37 & 8 & 141 & 32 \\
Total & - & - & - & - & 34 & 7 & 286 & 66 & 115 & 27 & 438 & 100 \\
\hline
\end{tabular}

Source: Authors' fieldwork. Rating: 01-Solid wastes sorted and packed into special sanitation bag. 02-Solid wastes sorted but packed into sacks or covered container. 03-Solid wastes not sorted but packed into special sanitation bag. 04-Solid wastes packed into open container. 05-Solid wastes dumped behind buildings or along road side or into seasonal stream. 


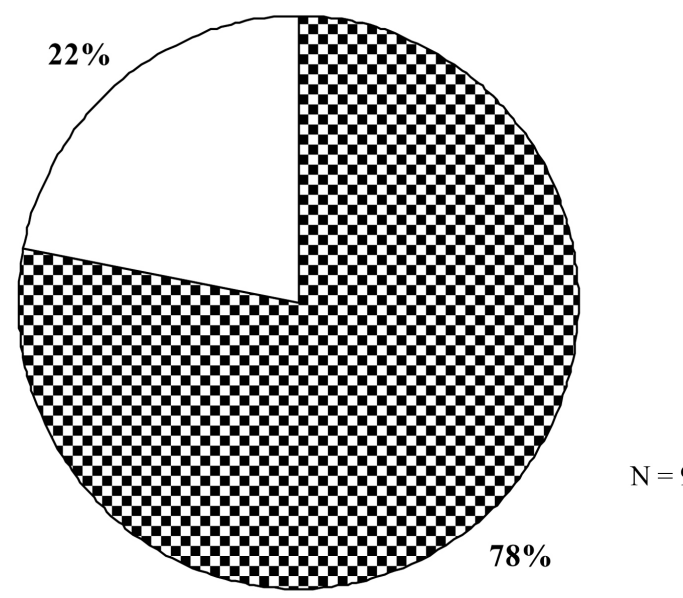

$\mathbf{0}$ Solid waste evacuated twice a week

$\square$ Solid waste not evacuated twice a week

Figure 6. Frequency of solid waste evacuation from collection. Source. Authors' fieldwork.

numerous health challenges from the above unhealthy methods of solid waste management. The people are prone to several health hazards, offensive odour and unsightliness from environmentally-unfriendly solid waste management methods as also identified in Yenagoa by the Federal Republic of Nigeria, National Bureau of Statistics, NBS (2009). Some of the health problems from the above unhealthy solid waste management methods may not be noticed immediately. The health conditions manifest after several years of stay in such areas through bio-accumulation and magnification of pollutants. Some of the easily identifiable diseases include cholera, typhoid, dysentery, skin infections. The leachate from solid waste contaminates sources of drinking water through percolation. The aquatic lives would also suffer extinction due to eutrophication. The discharge of too much nutrients in the form of nitrogen and phosphorous compounds amongst other pollutants into the streams through the dumping of solid wastes accelerate the growth of aquatic plants including algae as identified by Enger and Smith (2004).

\section{Conclusion}

The study showed that the extant laws for regulating building operations and other human activities in the state have not made an appreciable impact in the study area. Residents of the area still lack improved basic sanitation facilities. This is at variance with MDG 7, SDG 6 as well as SDG 11 which is to make cities and human settlements inclusive, safe, resilient and sustainable. It is clear from the above findings that poor condition of sanitary services seriously degrades the environmental quality of the study area in particular and Yenagoa at large. The study recommends the implementation of Infrastructural Improvement method of slum rehabilitation, which can improve the condition of sanitary services in the study area. 


\section{Acknowledgements}

The platform for this study was provided by the IGST, RS/UST to whom the authors are greatly indebted.

\section{References}

Adejuwon, J. O. (2012). Rainfall Seasonality in the Niger Delta Belt, Nigeria. Journal of Geography and Regional Planning, 5, 51-60.

Ayotamuno, J. M., \& Gobo, A. E. (2004). Municipal Solid Waste Management in Port Harcourt, Nigeria. Obstacles and Prospects. Management of Environmental Quality: An International Journal, 15, 389-398. https://doi.org/10.1108/14777830410540135

Duruzoechi, N. F. (1999). Urban and Regional Planning Law and Building Regulations in Nigeria (63 p). Owerri: Alphabet (Nig).

Ede, P. N., Ebakpa, A. F., \& Chukuigwe, E. C. (2007). Determination of Housing and Neighbourhood Quality for Yenagoa, Bayelsa State of Nigeria. Journal of the Nigerian Institute of Town Planners, 20, 99-118.

Enger, E. D., \& Smith, B. F. (2004). Environmental Science: A Study of Interrelationships (pp. 280-304). New-York: Mc Graw-Hill Companies Inc.

Ezenagu, V. C. (2000). Fundamentals of Housing (298 p). Awka: Fountain Publisher.

Federal Republic of Nigeria (1991). The Analytical Report on the Population Census of the Federal Republic of Nigeria (455 p).

Federal Republic of Nigeria (2009). Legal Notice on Publication of 2006 Census Final Results. Official Gazette, 96, B1-B42.

Federal Republic of Nigeria, National Bureau of Statistics, NBS (2009). Annual Abstract of Statistics (pp. 62-99).

Harcourt Adukeh Associates (2004). Yenagoa Maser Plan (187 p). Port Harcourt: Harcourt Adukeh Associates.

Igwilo, I. (2004). Environmental Studies Terminologies and Other Issues: A Comprehensive Guide to the study of Environmental Professions in Tertiary Institutions (pp. 104-105). Awka: Christon International Co. Ltd.

Jinadu, A. M. (2004). Urban Expansion and Physical Development Problem in Abuja: Implications for the National Urban Development Policy. Journal of the Nigerian Institute of Town Planners, 17, 15-29.

Jiriko, K. G. (2012). The Importance of Master Plan for the Development of Abuja Queried. Journal of the Nigerian Institute of Town Planners, 21, 94-116.

Lemma, T. (2005). A Comparison of Methodologies for Monitoring Slum Conditions within Millennium Development Goals: The Case Study of Addis Ababa, Ethiopia (102 p). Enschede: International Institute for Geo-Information Science and Earth Observation.

Obateru, O. I. (2003). Land Subdivision Basics (139 p). Ibadan: Penthouse Publications.

Olokesusi, F., \& Ogu, V. L. (1998). The Concept of "Healthy Cities" and Its Application to Sustainable Human Settlement Development. In K. Adeniji, \& V. L. Ogu (Eds.), Sustainable Physical Development in Nigeria (pp. 16-26). Ibadan: NISER.

Olurin, T. (2016). Residential Land Use Planning. In T. Agbola, L. Egunjobi, \& C. O. Olatubara (Eds.), Housing Development and Management. A Book of Readings (pp. 563-598). Ibadan: Artsmostfare Prints. 
Owei, O. B., \& Nwuzi, A. (2003). Partnership and Poverty Alleviation in Low Income Urban Settlements: The Case of the Child Friendly Cities Initiative in Port Harcourt, Nigeria. The Nigerian Journal of Environmental Sciences, 1, 213-234.

Simiyu, S. (2015). Determinant of Usage of Communal Sanitation Facilities in Informal Settlements of Kisumu, Kenya (19 p.). Stellenbosch: Environment \& Urbanization, International Institute for Environment and Development (IIED), Sapepublication.

Srinivas, H. (2009). Defining Squatter Settlements. http://www.gdrc.org/uem/define-Squatter.Html

UN-Habitat (2010). Development Context and the Millennium Agenda. The Challenge of Slums: Global Report on Human Settlements, 2003 (pp. 1-23).

United Nations (2015). Millennium Development Goals Report 2015 (pp. 60-61). New York, NY: United Nations.

United Nations (2016). The Sustainable Development Goals Report 2016 (pp. 32-33). New York, NY: United Nations.

Vidal, J. (2003). Every Third Person Will Be a Slum Dweller within 30 Years UN Agency Warns. 